Mujid dan Suyanto, Analisis Kesalahan Berbahasa dalam Penulisan Surat Undangan

\title{
Analisis Kesalahan Berbahasa dalam Penulisan Surat Undangan Organisasi Kemahasiswaan di Fakultas Ilmu Budaya Universitas Diponegoro
}

\author{
Mujid Farihul Amin dan Suyanto \\ Fakultas Ilmu Budaya Undip \\ moejid70@gmail.com dan suyanto@undip.ac.id
}

\begin{abstract}
Letter writing is a means of communication used to convey information from one party to another party. In writing a letter of invitation made by the student organization at the Faculty of Humanities, Diponegoro University speaking there are errors. Language errors can be classified in terms of spelling mistakes and grammatica lerrors from the corner. From the point of spelling mistakes, such as errors in writing on the letter head, dated letters, numbers, attachment, respect, and the contents of the letter. Errors of grammar corner there are two, namely the use of pronouns in the paragraph cover letter and there are still fragmentary sentences.
\end{abstract}

Keywords: language errors, invitation letter, the student organization.

\section{Intisari}

Surat adalah sarana komunikasi tertulis yang digunakan untuk menyampaikan informasi dari satu pihak ke pihak lain. Dalam penulisan surat undangan yang dilakukan oleh organisasi kemahasiswaan di Fakultas Ilmu Budaya Universitas Diponegoro terdapat kesalahan berbahasa. Kesalahan berbahasa tersebut dapat digolongkan kesalahan dari sudut ejaan dan kesalahan dari sudut tata bahasa. Kesalahan dari sudut ejaan, misalnya kesalahan dalam penulisan di kepala surat, tanggal surat, nomor, lampiran, hal, dan isi surat. Kesalahan dari sudut tata bahasa ada dua, yaitu pemakaian kata ganti dalam alinea penutup isi surat dan masih terdapat kalimat fragmentaris.

Kata-kata Kunci: kesalahan berbahasa, surat undangan, organisasi mahasiswa.

\section{Pendahuluan}

Manusia sebagai mahluk sosial dalam kehidupan sehari-hari tentu memerlukan komunikasi dengan manusia yang lain. Alat/sarana yang digunakan untuk berkomunikasi verbal adalah bahasa. Dapat dikatakan bahwa bahasa memiliki peranan yang sangat penting dalam kehidupan manusia. Pentingnya bahasa itu ternyata mencakup segala aspek kehidupan manusia. Segala sesuatu yang dirasakan, dialami, dihayati, dan dipikirkan oleh manusia hanya dapat diketahui manusia lain jika telah diungkapkan dengan bahasa. Melalui bahasa, manusia berkomunikasi dengan manusia lain untuk berbagai keperluan dalam kehidupannya, baik secara lisan maupun tulis dan secara langsung maupun tidak langsung.

Salah satu alat komunikasi tertulis yang digunakan dalam berkomunikasi adalah surat. Surat selain sebagai sarana komunikasi, juga mempunyai berbagai fungsi lain. Fungsi-fungsi 
tersebut adalah 1) sebagai alat untuk menyampaikan pemberitahuan, permintaan atau permohonan, buah pikiran atau gagasan; 2) alat bukti tertulis; 3) alat untuk mengingat; 4) bukti historis, dan 5) pedoman kerja (Sudarsa dkk, 1991: 3).

Dilihat dari segi bentuk, isi, dan bahasanya, menurut Sudarsa (1991:3) surat dapat digolongkan atas tiga jenis, yaitu 1) surat pribadi, 2) surat dinas, dan 3) surat niaga. Dalam surat dinas terkandung informasi-informasi tertentu yang dapat berupa perintah, pemberitahuan, undangan, tugas, permintaan, teguran, dan lain-lain. Untuk itu, surat hendaknya ditulis menggunakan bahasa yang sangkil dan mangkus, bahasa yang baik dan benar sesuai dengan kaidah bahasa Indonesia yang berlaku. Kesalahan-kesalahan yang sering terjadi dalam penulisan surat dinas adalah penggunaan bahasa yang tidak baku. Demikian juga dalam surat-menyurat yang dilakukan oleh organisasi kemahasiswaan di Fakultas Ilmu Budaya Undip masih terdapat kesalahan-kesalahan dari sudut bahasa yang digunakan.

Kesalahan secara garis besar dapat dipilah menjadi dua, yaitu kesalahan dari sudut ejaan dan sudut tata bahasa. Kedua jenis kesalahan ini untuk pembetulannya sudah ada parameter/aturannya, yaitu untuk ejaan patokannya adalah Pedoman Umum Ejaan Bahasa yang Disempurnakan (1988) dan untuk tata bahasa pedomannya adalah Tata Bahasa Baku Bahasa Indonesia (1988).

\section{Metode Penelitian}

Metode yang digunakan dalam penelitian ini adalah metode deskriptif analitis. Arikunto (2010: 3) mengatakan metode deskriptif merupakan penelitian yang benar-benar hanya memaparkan apa yang terdapat atau terjadi dalam sebuah kancah lapangan, atau wilayah tertentu. Dalam penelitian ini penulis menggunakan metode deskriptif analitis dengan tujuan agar dapat mendeskripsikan kesalahan berbahasa dalam penulisan surat undangan organisasi kemahasiswaan di Fakultas Ilmu Budaya Universitas Diponegoro.

Sumber data dalam penelitian ini adalah surat undangan yang dikirimkan oleh organisasi kemahasiswaan di Fakultas Ilmu Budaya Universitas Diponegoro kepada Pembantu Dekan III Fakultas Ilmu Budaya Universitas Diponegoro bulan Januari 2014 sampai dengan bulan Juni 2014. Teknik pengumpulan data yang penulis gunakan dalam penelitian ini adalah teknik dokumentasi. Menurut Arikunto (2010: 274), "Teknik dokumentasi adalah teknik yang digunakan untuk mencari data, hal-hal variabel yang berupa catatan, buku-buku, majalah, surat kabar, majalah, prasasti, notulen rapat dan lain-lain”. Dokumen yang digunakan dalam penelitian ini adalah surat undangan yang dikirimkan oleh organisasi kemahasiswaan di Fakultas Ilmu Budaya Universitas Diponegoro kepada 
Pembantu Dekan III Fakultas Ilmu Budaya Universitas Diponegoro bulan Januari 2014 sampai dengan bulan Juni 2014.

Adapun langkah kerja yang dilakukan penulis adalah membaca surat undangan yang diarsipkan oleh Pembantu Dekan III Fakultas Ilmu Budaya Universitas Diponegoro dari bulan Januari 2014 sampai dengan bulan Juni 2014 dan kemudian membuat catatan yang berkaitan kesalahan berbahasa dalam surat undangan yang dikirimkan oleh organisasi kemahasiswaan di Fakultas Ilmu Budaya Universitas Diponegoro kepada Pembantu Dekan IIIFakultas Ilmu Budaya Universitas Diponegoro.

Berdasarkan metode penelitian yang peneliti gunakan dan objek penelitian berupa surat yang dikirimkan oleh organisasi kemahasiswaan di Fakultas Ilmu Budaya Universitas Diponegoro kepada Pembantu Dekan IIIFakultas Ilmu Budaya Universitas Diponegoro, adapun cara menganalisis data yaitu mengidentifikasi, mengklasifikasi, menganalisis, membahas hasil analisis, dan simpulan.

\section{Kesalahan Berbahasa dalam Penulisan Surat Undangan Organisasi Kemahasiswaan}

Untuk membetulkan segala sesuatu yang salah, harus diketahui terlebih dahulu letak kesalahannya dengan tepat. Demikian juga untuk menganalisis kesalahan berbahasa dalam penulisan surat undangan organisasi kemahasiswaan di Fakultas Ilmu Budaya Undip perlu diketahui terlebih dahulu letak kesalahannya dengan tepat. Yang dimaksud dengan kesalahan adalah segala sesuatu yang menyimpang dari aturan, norma, atau prosedur baku yang berlaku.

Kesalahan dalam pemakaian berbahasa/berbahasa secara garis besar dapat dikelompokkan menjadi dua, yaitu kesalahan dalam bidang ejaan dan kesalahan dalam bidang tata bahasa. Acuan/parameter/tolak ukur untuk menganalisis kesalahan ejaan dalam bahasa Indonesia sudah cukup jelas, yaitu Pedoman Umum Ejaan Bahasa Indonesia yang Disempurnakan $(E y D)$. Jadi, segala macam penulisan terkait dengan segi ortografis/tata tulis dikatakan salah apabila tidak sesuai dengan aturan-aturan atau ketentuan-ketentuan yang terdapat dalam Pedoman Umum Ejaan Bahasa Indonesia yang Disempurnakan (EyD).

Kesalahan yang berkait dengan tata bahasa, dalam bahasa Indonesia juga sudah jelas parameter/tolak ukurnya. Parameter/pedoman/tolak ukur berbahasa kaitannya dengan tata bahasa dalam bahasa Indonesia adalah aturan-aturan/kaidah-kaidah yang termaktub dalam Tata Bahasa Baku Bahasa Indonesia. Jadi, pemakaian bahasa dianggap salah/tidak tepat dari 
sudut tata bahasa apabila penyusunannya tidak sesuai dengan aturan-aturan/kaidah-kaidah yang termaktub dalam Tata Bahasa Baku Bahasa Indonesia.

\section{Kesalahan Ejaan/Tata Tulis}

Kesalahan dari segi tata tulis/ejaan yang masih terdapat dalam surat undangan yang disusun oleh organisasi kemahasiswaan di Fakultas Ilmu Budaya Universitas Diponegoro meliputi: kesalahan penulisan pada kepala surat, tanggal surat, lampiran, hal/perihal, alamat surat, dan isi surat.

(1) Kesalahan Penulisan pada Kepala Surat

Dalam penulisan kepala surat/kop surat masih terdapat beberapa kesalahan, yaitu 1) penulisan kata Jalan disingkat menjadi JL. atau Jl. bahkan ada yang langsung nama jalannya. Sesuai EyD harusnya ditulis lengkap dan kalau mau disingkat Jln. Bukan JL. atau J1. 2) penulisan nama jalan tidak seragam, ada yang menuliskan Prof. Sudharto, SH, Prof. H. Soedarto, SH, Prof. Soedarto, S.H., Prof. Sudhartto, SH., dan 3) penulisan kata telepon menjadi telpon dan ada yang disingkat menjadi Telp. atau Tlpn. Sesuai aturan harusnya ditulis lengkap Telepon.

(2) Kesalahan Penulisan pada Tanggal Surat

Kesalahan-kesalahan yang terdapat dalam penulisan tanggal surat sebagai berikut.

Penulisan tanggal surat didahului nama tempat, contoh: a) Semarang, 6 Maret 2014, b) Semarang, 14 April 2014, c) Semarang, 5 Mei 2014, dan d) Semarang, 23 Juni 2014. Seharusnya, sebelum tanggal tidak dicantumkan nama kota karena nama kota itu sudah tercantum pada kepala surat. Penulisan angka tanggal yang terdiri atas satu angka di depannya ditambah angka nol, contoh: 04 Juni 2014. Penambahan angka nol tersebut tidak ada gunanya sehingga lebih baik dan lebih efektif tidak dituliskan.

(3) Kesalahan Penulisan di Lampiran

Berkaitan dengan penulisan lampiran kesalahan yang terjadi adalah penulisan kata lampiran ditulis Lamp tanpa tanda baca apa pun. Padahal yang betul ditulis lengkap atau disingkat Lamp. (ada tanda titiknya). Selain itu, terdapat tulisan Lamp tetapi tidak ada sesuatu yang dilampirkan bersama surat, contoh: Lamp : -. Kalau tidak ada sesuatu yang dilampirkan bersama surat jangan ditulis Lampiran atau Lamp.

(4) Kesalahan Penulisan di Hal/Perihal

Terdapat penulisan Hal/Perihal yang isinya ditulis dengan diberi garis bawah, contoh: Hal: Undangan. Yang benar, untuk Hal/Perihal berkaitan dengan isi surat tidak perlu diberi garis bawah. 
(5 Kesalahan Penulisan di Alamat Surat

Dalam penulisan alamat surat, terdapat beberapa kesalahan, yaitu: 1) diawali dengan preposisi kepada. Seharusnya tidak perlu dituliskan preposisi Kepada karena dalam surat tersebut tidak didahului dengan preposisi Dari. Selain itu, sudah seharusnyalah surat-surat itu dikepadakan sehingga akan lebih hemat/tidak mubazir kalau langsung ditulis Yth. diikuti nama jabatan atau orang yang dituju. 2) Alamat yang dituju tidak ditulis secara lengkap

Contoh: Yth. Drs. Mujid Farihul Amin, M.Pd.

Di Tempat

Kepada Yth.

Drs. Mujid Farihul A,M.Pd.

Di tempat

Sesuai dengan aturan penulisan alamat surat, harusnya ditulis sebagai berikut.

Yth. Drs. Mujid Farihul Amin, M.Pd.

Pembantu Dekan III

Fakultas Ilmu Budaya Undip

Semarang

atau

Yth. Pembantu Dekan III

Fakultas Ilmu Budaya Undip

Semarang

(6) Kesalahan Penulisan di Isi Surat

- Alinea Pembuka dan Isi

Dalam surat undangan alinea pembuka dan isi sering dijadikan satu. Kesalahan penulisan yang terdapat dalam alinea ini sebagai berikut.

- Sehubungan dengan diselenggarakannya acara Peringatan hari Lingkungan yang dilaksanakan oleh Dimas Volunteer Group dan Maritime Study Group Fakultas Ilmu Budaya pada:

- Sehubungan dengan adanya roadshow yang telah dilaksanakan PSDM BEM FIB, kami akan mengadakan Forum Lingkar PSDM untuk membahas lebih lanjut hasil diskusi saat roadshow, yang akan dilakasanakan pada...

- Sehubungan akan dilaksanakan kegiatan Achievement Motivation Training (AMT) yang akan diselenggarakan pada ...

- Sehubungan dengan diselenggarakannya Focus Group Discussion 2014 yang bertema "FIB GOES TO PIMNAS XXVIII" oleh Kementerian RISTEK Badan Eksekutif Mahasiswa dan UKM RC (Research Club) Fakultas Ilmu Budaya Universitas Diponegoro pada ...

- Waktu: $08.00 \mathrm{~s} / \mathrm{d}$ selesaidan Waktu: $08.30 \mathrm{~s} / \mathrm{d}$ selesai 
Mujid dan Suyanto, Analisis Kesalahan

Kesalahan penulisan yang terdapat pada data di atas adalah kesalahan penulisan kosakata yang berasal dari bahasa asing. Kosakata yang berasal dari bahasa asing apabila terdapat dalam tulisan yang konteksnya bahasa Indonesia harusnya ditulis dengan huruf miring. Jadi kata Volunteer Group, Maritime Study, roadshow, Achievement Motivation Training, Focus Group Discussion 2014, Research Club harusnya ditulis dengan huruf miring menjadi Volunteer Group, Maritime Study, roadshow, Achievement Motivation Training, Focus Group Discussion 2014, Research Club. Untuk data terakhir, kesalahannya adalah pada penulisan s/d harusnya ditulis tidak dengan garis miring tetapi dengan tanda titik s.d. atau ditulis dengan lengkap sampai dengan bisa juga diganti dengan tanda hubung (-).

- Alinea Penutup

Kesalahan dari segi penulisan dalam alinea penutup dapat dilihat pada data berikut.

(a) Atas perhatian dan kerjasamanya kami ucapkan terima kasih.

(b) Atas perhatian dan kerjasama Bapak, kami ucapkan terima kasih.

(c) Atas perhatian Saudara/i kami sampaikan terimakasih.

Pada data a) dan b) penulisan kata kerjasamanya dan kerjasama tidak tepat, harusnya yang benar adalah kerja sama Bapak dan kerja sama. Pada data c), kesalahan terdapat dalam penulisan Saudara/i dan terima kasih yang betul adalah Bapak dan terima kasih.

\section{Kesalahan dari Segi Tata Bahasa}

(1) Pemakaian Kata Ganti

Dalam alinea penutup, sering terdapat kesalahan pemakaian kata ganti -nya. Kata ganti -nya merupakan kata ganti orang/pronomina persona yang merujuk kepada orang ketiga bukan kata ganti orang kedua, contoh: Atas perhatiannya, kami ucapkan terima kasih.

Padahal dalam surat-menyurat tersebut (surat undangan) yang diajak berkomunikasi adalah orang kedua. Jadi, pronomina -nya dalam kata perhatiannya tidak merujuk kepada orang yang diajak berkomunikasi tetapi merujuk kepada orang lain di luar komunikan dan komunikator. Untuk itu, alinea penutup tersebut harus dibetulkan sehingga berbunyi: Atas perhatian Bapak/Ibu/Saudara, kami ucapkan terima kasih.

(2) Kalimat Fragmentaris

Kalimat fragmentaris adalah kallimat yang belum lengkap dari segi makna tetapi sudah dibri intonasi akhir sehingga ada informasi yang hilang atau informasinya belum lengkap. Tentu 
Mujid dan Suyanto, Analisis Kesalahan

saja, apabila terdapat kalimat seperti ini dalam sebuah surat akan membingungkan pemahaman pembaca terhadap isi informasi atau pesan yang akan disampaikan, contoh:

1) Sehubungan akan dilaksanakannya kegiatan diskusi sospol "Haruskah kita melawan? Sampai kapan kita menderita?" yang akan diselenggarakan pada: hari/ tanggal: Rabu, 18 Juni 2014

waktu: $15.30-18.00$

tempat: Crop Circle

Oleh karena itu, kami selaku panitia pelaksana bermaksud meminta kesediaan Bapak untuk dapat hadir pada acara tersebut.

2) Sehubungan akan dilaksanakannya kegiatan diskusi sospol "FIB Bicara Pilpres" yang akan diselenggarakan pada:

hari/ tanggal: Kamis, 22 Juni 2014

waktu: $15.00-18.00$

tempat: Crop Circle

Oleh karena itu, kami selaku panitia pelaksana bermaksud meminta kesediaan Bapak untuk dapat hadir pada acara tersebut.

3) Sehubungan dengan adanya pentas "Yang Tersisa di Taman Kota", yaitu sebuah pementasan drama yang disutradarai oleh Galih Pandu Adi yang bekerja sama dengan Keluarga Mahasiswa Sastra Indonesia (KMSI) Undip dan Teater Emper Kampus (Emka) Semarang, yang akan diselenggarakan pada:

hari / tanggal: Rabu, 18 Juni 2014

pukul: 18.30 - selesai

tempat: Taman Kampus FIB Undip Tembalang

Maka dengan ini kami selaku tim produksi mengharap kehadiran Bapak/Ibu dalam acara pentas drama tersebut.

Kesalahan yang terdapat pada data 1) sampai 3) adalah kalimat pada data tersebut belum selesai tapi sudah diselesaikan sehingga kalimatnya menjadi kalimat fragmentaris. Seharusnya setelah disebutkan tempat, pada baris berikutnya jangan dilanjutkan dengan huruf kapital karena pemakaian huruf kapital tersebut menandai awal kalimat. Tulis saja dengan huruf kecil karena bagian tersebut merupakan kelanjutan dari bagian sebelumnya sehingga maknanya akan menjadi utuh tidak fragmentaris lagi.

\section{Simpulan}

Berdasarkan penelitian dan pembahasan kesalahan berbahasa yang telah peneliti lakukan pada surat undangan yang disusun oleh organisasi kemahasiswaan di Fakultas Ilmu Budaya Universitas Diponegoro, dapat disimpulkan bahwa terdapat kesalahan berbahasa dalam penulisan surat undangan tersebut. Kesalahan berbahasa dapat dilihat dari dua sudut, yaitu kesalahan dari sudut ejaan dan kesalahan dari sudut tata bahasa. Kesalahan dari sudut ejaan, misalnya kesalahan dalam penulisan di kepala surat, tanggal surat, nomor, lampiran, hal, dan 
isi surat. Kesalahan dari sudut tata bahasa ada dua, yaitu pemakaian kata ganti dalam alinea penutup isi surat dan masih terdapat kalimat fragmentaris.

Kesalahan dari sudut ejaan karena penulisan pada bagian-bagian surat tidak sesuai dengan aturan-aturan yang ada dalam Pedoman Umum Ejaan Bahasa Indonesia yang Disempurnakan (EyD). Kesalahan penulisan surat undangan dari sudut tata bahasa karena penyusunan kalimat tidak sesuai dengan aturan-aturan atau kaidah-kaidah yang ada dalam Tata Bahasa Baku Bahasa Indonesia.

\section{Daftar Pustaka}

Alwi, Hasan dkk. (ed). 2003. Tata Bahasa Baku Bahasa Indonesia. Jakarta: Balai Pustaka.

Anam, Samsul. 2012. "Analisis Kesalahan EyD dalam Surat Undangan Dinas di Kantor Kecamatan Peninjauan Kabupaten Oku" dimuat dalam Lentera Pendidikan Volume V Nomor 3 Oktober 2012.

Arikunto, Suharsimi. 2010. Prosedur Penelitian: Suatu Pendekatan Praktik. Jakarta: Rineka Cipta.

Pusat Pembinaan dan Pengembangan Bahasa. 1988. Pedoman Umum Ejaan Bahasa Indonesia yang Disempurnakan. Jakarta: PN Balai Pustaka.

Pusat Pembinaan dan Pengembangan Bahasa. 1988. Pedoman Umum Pembentukan Istilah. Jakarta: PN Balai Pustaka.

Sudarsa, Caca. 1989. "Ancangan Mutakhir Penulisan Surat Resmi Indonesia”. Bahan Penyuluhan Surat-Menyurat di Pusdiklat Departemen Pendidikan dan Kebudayaan. Jakarta: Pusat Bahasa.

Sudarsa, Caca dkk. 1991. Seri Penyuluhan 2: Surat-Menyurat dalam Bahasa Indonesia. Jakarta: Pusat Pembinaan dan Pengembagan Bahasa, Departemen Pendidikan dan Kebudayaan.

Sumantri, Maman dkk. 1985. Pedoman Surat-Menyurat. Jakarta: Pusat Bahasa.

Sudaryono. 1988. Surat-menyurat dalam Bahasa Indonesia. Bandung: Angkasa. 